\title{
Analyses of freshwater stress with a couple ground and surface water model in the Pra Basin, Ghana
}

\author{
George Owusu' ${ }^{1}$ Alex B. Owusu ${ }^{1}$ Ebenezer Forkuo Amankwaa ${ }^{1}$. \\ Fatima Eshun ${ }^{1}$
}

Received: 27 May 2014/ Accepted: 4 March 2015/Published online: 4 April 2015

(C) The Author(s) 2015. This article is published with open access at Springerlink.com

\begin{abstract}
The optimal management of water resources requires that the collected hydrogeological, meteorological, and spatial data be simulated and analyzed with appropriate models. In this study, a catchment-scale distributed hydrological modeling approach is applied to simulate water stress for the years 2000 and 2050 in a data scarce Pra Basin, Ghana. The model is divided into three parts: The first computes surface and groundwater availability as well as shallow and deep groundwater residence times by using POLFLOW model; the second extends the POLFLOW model with water demand (Domestic, Industrial and Agricultural) model; and the third part involves modeling water stress indices-from the ratio of water demand to water availability-for every part of the basin. On water availability, the model estimated long-term annual Pra river discharge at the outflow point of the basin, Deboase, to be $198 \mathrm{~m}^{3} / \mathrm{s}$ as against long-term average measurement of $197 \mathrm{~m}^{3} / \mathrm{s}$. Moreover, the relationship between simulated discharge and measured discharge at 9 substations in the basin scored Nash-Sutcliffe model efficiency coefficient of 0.98, which indicates that the model estimation is in agreement with the long-term measured discharge. The estimated total water demand significantly increases from $959,049,096 \mathrm{~m}^{3} /$ year in 2000 to $3,749,559,019 \mathrm{~m}^{3} /$ year in $2050(p<0.05)$. The number of districts experiencing water stress significantly increases ( $p=0.00044)$ from 8 in 2000 to 21 out of 35 by the year 2050. This study will among other things help the stakeholders in water
\end{abstract}

George Owusu

owusugeorge@ug.edu.gh

1 Department of Geography and Resource Development, University of Ghana, P. O. Box LG 59, Accra, Ghana resources management to identify and manage water stress areas in the basin.

Keywords PCRaster - GIS - River discharge - Water vulnerability · Groundwater · POLFLOW

\section{Introduction}

Water vulnerability is often estimated from the ratio of water demand and water availability, with water stress occurring when the local water demand exceeds the local water availability (Wada 2008). Ledger (1972) pioneered the studies of water availability and water demand in a case study in Warwickshire Avon, England. However, Falkenmark (1989) was the first to have estimated water stress indices based on available freshwater resources and water per capita. Falkenmark's estimation did not account for industrial and agricultural water demand, but Oki and Kanae (2006) accounted for them in their estimation of water stress.

At continental levels, there are many macroscale hydrological models (MHMs) that have been developed to simulate water stress by using water availability and water demand (Takahashi et al. 2000; Vorosmarty et al. 2000; Oki et al. 2001; Alcamo et al. 2003a, b; Arnell 2003; Doll et al. 2003; Widen-Nilsson et al. 2007). However, due to their lower spatial resolution of $0.5^{\circ}$, the MHMs may not be suitable for catchment water vulnerability analysis. Catchment models such as MIKE-SHE (DHI 2000), MIKE-11 (Havnø et al. 1995), HEC-RAS (Brunner 2008), TOPKAPI(Ciarapica and Todini 2002), TOPMODEL (Beven and Kirkby 1979), MODFLOW (Baalousha 2012), and LISFLOOD (Van Der Knijff et al. 2008) can be used to estimate water availability, but they lack water demand 
component. While these catchment models are powerful in the estimation of water availability, they are not suitable for long-term average water availability simulation. Moreover, they loosely model coupled relationship between surface water and groundwater.

POLFLOW is a catchment-scale hydrological model developed for the simulation of water and nutrient fluxes (De Wit 2001). POLFLOW is embedded in PCRaster (Karssenberg 1996, 2002) language. Though the model has been developed for nutrient fluxes, the water flux component can be separated and used for another application. For instance, POLFLOW has been separately used for the estimation of changes in surface and groundwater resources (Jarsjö et al. 2004; Durdu 2005). "The long-term average total runoff, the groundwater recharge index, and the groundwater residence time are the determinant factors in the model" (Durdu 2005). The POLFLOW model has also been applied in several other European river basins (De Wit 2001; Greffe 2003; Jarsjö et al. 2004; Durdu 2005). Like other similar catchment models, POLFLOW lacks water demand component. This study extends POLFLOW water flux model with water demand module for the estimation of water stress for Pra Basin of Ghana.

In the Pra Basin, IPCC (2007) projected a slight increase in rainfall and $3-4{ }^{\circ} \mathrm{C}$ increase in temperature by the end of the twenty-first century. How will climate change affect the basin's hydrology? Opoku-Ankomah (2000) used a lumped model, for the whole of the basin, to compute water vulnerability index using only surface water discharge and total population of the basin. Though the study computed vulnerability index of 442 persons $/ 10^{6} \mathrm{~m}^{3}$ of surface water, it could not spatially identify those areas in the basin that are experiencing vulnerability. The complex relationship between water supply and water demand compelled Water Resources Commission (Water-Resources-Commission 2012) of Ghana to establish the Pra River Basin Board-a decentralized management body to facilitate the implementation of Integrated Water Resources Management (IWRM). This body seeks to promote the coordinated development and management of water, land, and related resources in order to maximize the resultant economic and social welfare in an equitable manner without compromising the sustainability of vital ecosystems.

The main objective of the study was to develop a catchment-scale distributed hydrological model for simulation of water stress, for the years 2000 and 2050, in the Pra Basin, Ghana. The first specific objective was to estimate surface and groundwater availability. Secondly, the study extends POLFLOW model by adding a water demand model. The third objective was to compute water stress indices-from the ratio of water demand and water availability in the basin. The first hypothesis of the study is that there will be no significant difference between the estimated water demand in 2000 and 2050, while the second hypothesis is that the number of districts experiencing water stress in the basin will not significantly differ in the years 2000 and 2050.

\section{Methodology}

\section{The study area}

The Pra Basin with an area of $23,000 \mathrm{~km}^{2}$ is one of the south-western catchments (Opoku-Ankomah 2000) that occupy $20 \%$ of the land area of Ghana (Fig. 1).

The basin is a home to four administrative regionsAshanti, Eastern, Western, and Central-as well as 41 districts in Ghana. While population in the basin increases from southern part to the north, annual rainfall and temperature decrease with increasing levels of evapotranspiration. These climatic elements are also seasonally based, which brings about frequent climatic and hydrological droughts in the dry season and flooding in the rainy season. The basin has a populated farmland and rapidly developing urban and suburban areas. Its agriculture is mainly rain fed, and there is high agricultural water demand for irrigation. There is also high industrial and domestic water demand due to economic growth and high population growth. Moreover, there are already some districts in the basin, though not urban, where water demand is outgrowing water availability or supply, and this is further exacerbated by the continuous growth of population and climate change. The basin is divided into three sub-basins and they include Offin river, Oda river, and Birim river. The Offin is found in the upper west of the basin, while the Oda is found in the middle part of the basin with Birim in the eastern part (Fig. 1). The basin is also the home of the largest natural lake (Bosomtwe) in Ghana.

\section{Theory and calculation}

In this study, water stress is modeled by dividing water demand by water availability (Wada 2008). The model is divided into 3 parts (and they are all captured in Fig. 2). The first part computes water availability by using POLFLOW (De Wit 2001) model; the second part extends the POLFLOW model with water demand model. The third part involves modeling water vulnerability indices for the basin. In this study, POLFLOW model is extended by accounting for water demand/use in estimating long-term average water fluxes in Pra Basin (Fig. 2). Moreover, this model unlike the original POLFLOW will estimate annual river discharge (Q) by including only part of groundwater recharge that is less than or equal to one year old because the model temporal framework is annually based (De Wit 2001). 
Fig. 1 The location of the study area

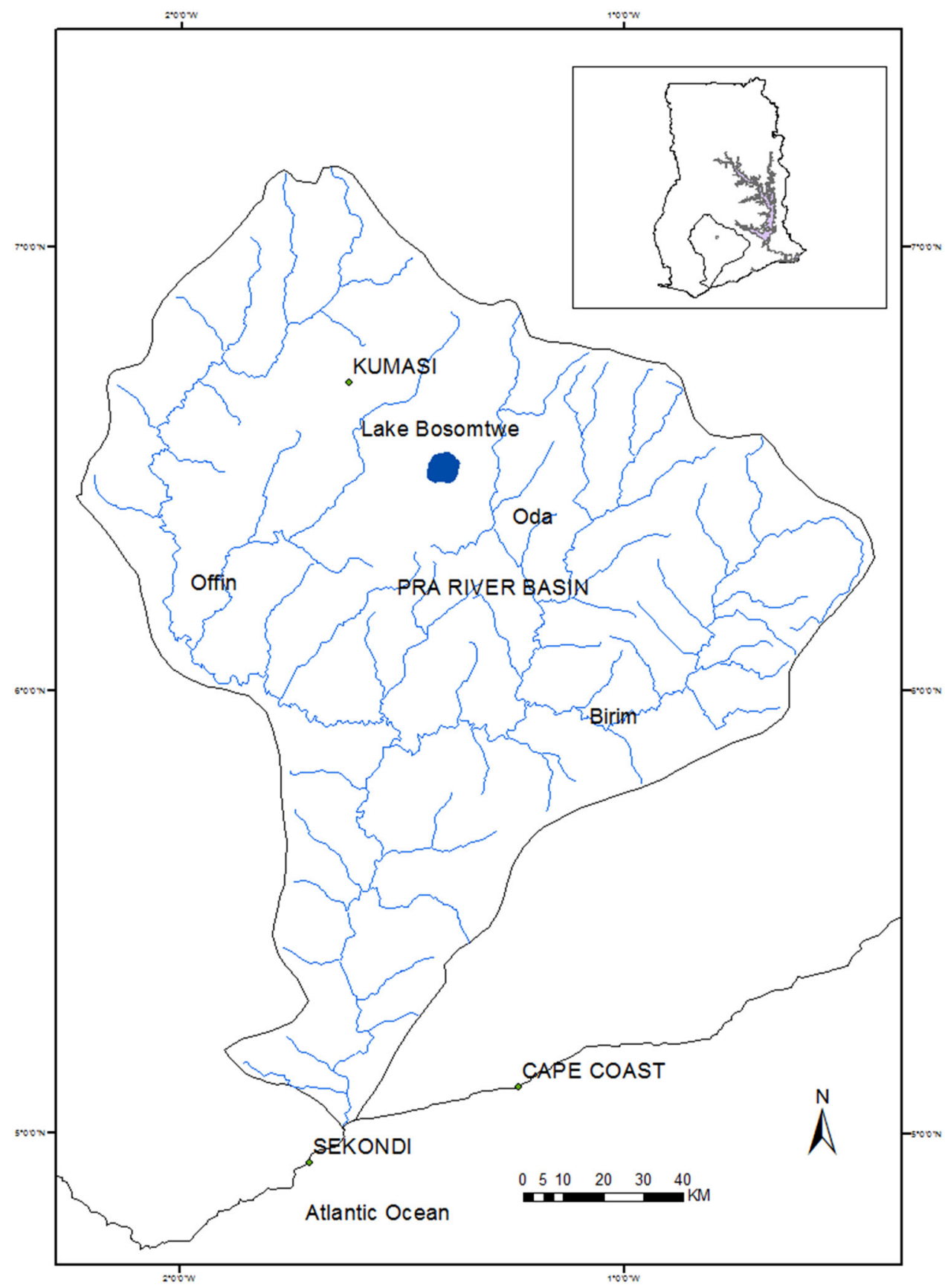

soil and land cover through the use of crop coefficients. Meinardi et al. (1994) estimated actual evapotranspiration based on Turc (1954) precipitation and potential evapotranspiration $\left(\mathrm{E}_{\mathrm{p}}\right)$ model as:

$E_{\mathrm{a}}=\frac{P}{\sqrt{\left(0.9+\frac{P^{2}}{E_{\mathrm{p}}^{2}}\right)}}$.

Langbein (1949) estimated $\mathrm{E}_{\mathrm{p}}$ as a function of long-term temperature $\left(T,{ }^{\circ} \mathrm{C}\right)$ as:

$E_{\mathrm{p}}=325+(21 \times T)+\left(0.9+T^{2}\right)$. and (2) Meinardi et al. (1994) methods. Wendland (1992) calculated evapotranspiration by empirically relating it to 
Fig. 2 The conceptual framework and flowchart of the model. Legend: $R_{\mathrm{S}}$ is surface runoff and soil interflow contribution; $R_{\mathrm{gw}}$ is amount of precipitation surplus available for groundwater recharge; PET is potential evapotranspiration; crop coeff is crop coefficient; $f_{\mathrm{gw}}$ is shallow groundwater index; $f_{\mathrm{dgw}}$ is deep groundwater index

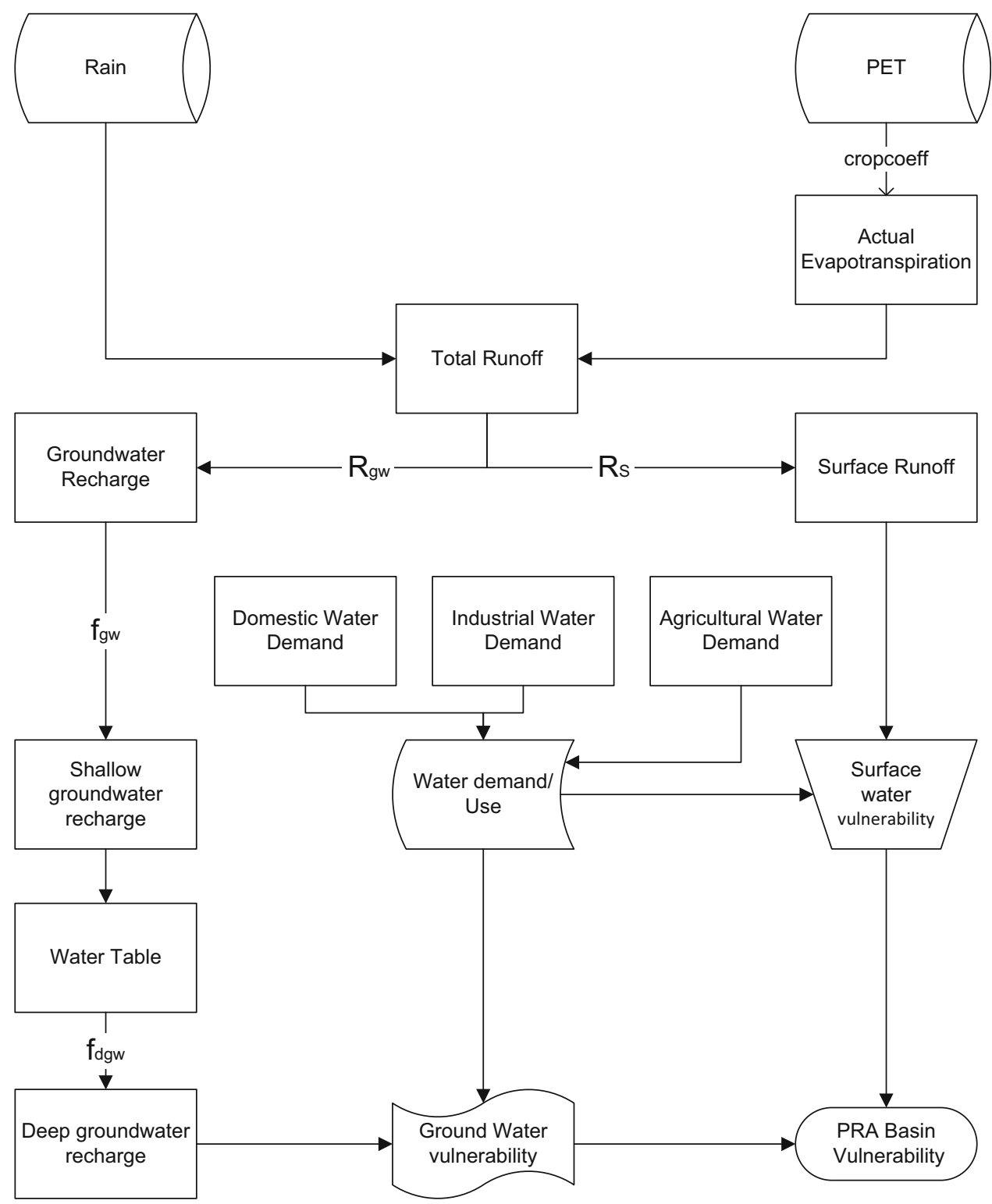

It can be seen in Fig. 2 that total runoff $(\mathrm{Q})$ is also equal to:

$Q=R_{\mathrm{s}}+R_{\mathrm{gw}}$

where $R_{\mathrm{S}}$ is surface runoff and soil interflow contribution, $R_{\mathrm{gw}}$ is amount of precipitation surplus available for groundwater recharge. The groundwater recharge $(\mathrm{GW})$ (Jarsjö et al. 2004) was estimated as:

$R_{\mathrm{gw}}=\mathrm{GW}=f_{\mathrm{gw}} \cdot Q$

where $f_{\mathrm{gw}}$ is groundwater index. The surface runoff in Eq. (4) was estimated as:

$R_{\mathrm{S}}=\left(1-f_{\mathrm{gw}}\right) \cdot Q$ $f_{\mathrm{gw}}=$ if (groundwater level near the surface then, water,

$$
\operatorname{else}(1+(3(\text { slope }+0.0001))) \text {. }
$$

The deep groundwater recharge index $\left(f_{\text {dgw }}\right)$ was described as a function of aquifer type, texture of the top soil, groundwater level, slope, and land use:

$f_{\mathrm{dgw}}=f_{\mathrm{dqw}}^{\mathrm{aq}} \cdot f_{\mathrm{dqw}}^{\mathrm{so}} \cdot f_{\mathrm{dqw}}^{\mathrm{lc}} \cdot\left(1-\left(\text { slope }+10^{-7}\right)^{0.4}\right)$

where "aq" is related to aquifer characteristics, "so" is related to soil characteristics, and "lc" is related to land use characteristics (Tables 1,2).

Once groundwater recharges were computed, the residence time - the time it takes for underground water to join surface water-was computed as a function of groundwater 
Table 1 The tabulated parameter values of deep groundwater recharge index and aquifer type $\left(f_{\text {dqw }}^{\text {aq }}\right)$, primary porosity(pp), and conductivity of the aquifer (ca) (Meinardi et al. 1994)

\begin{tabular}{llll}
\hline Aquifer type & $f_{\mathrm{dqw}}^{\mathrm{aq}}$ & $\mathrm{pp} \mathrm{(-)}$ & $\left.\mathrm{ca}_{(\mathrm{mday}}{ }^{-1}\right)$ \\
\hline Unconsolidated sedimentary aquifer: good permeability & 0.95 & $0.10-0.15$ & $35-52$ \\
Unconsolidated sedimentary aquifer: poor permeability & 0.80 & $0.05-0.10$ & $17-35$ \\
Consolidated sedimentary aquifer: good permeability & 0.70 & $0.10-0.15$ & $35-52$ \\
Consolidated sedimentary aquifer: poor permeability & 0.50 & $0.05-0.10$ & $0.10-0.15$ \\
Igneous and metamorphous rock: modest permeability & 0.40 & $0.05-0.10$ & $35-52$ \\
Igneous and metamorphous rock: poor permeability & 0.10 & $0.10-0.15$ & $17-35$ \\
Incidentally brackish groundwater & 0.80 & $0.05-0.10$ & $35-52$ \\
Generally brackish or saline groundwater & 0.80 & 0 & $17-35$ \\
Surface water & 0.00 & &
\end{tabular}

Table 2 The tabulated parameter values of soil $\left(f_{\mathrm{dqw}}^{\mathrm{so}}\right)$ and land cover $\left(f_{\mathrm{dqw}}^{\mathrm{lc}}\right)$ indices (Meinardi et al. 1994)

\begin{tabular}{lclc}
\hline Soil type & $f_{\text {dqw }}^{\text {so }}$ & Land cover & $f_{\text {dqw }}^{\text {lc }}$ \\
\hline Sand & 0.95 & Forest & 1.00 \\
Loam/sand & 0.75 & Permanent crops, others & 0.95 \\
Loam & 0.50 & Agricultural land & 0.90 \\
Loam/clay & 0.25 & Built up & 0.40 \\
Clay & 0.05 & Water & 0.00 \\
Groundwater near surface & 0.10 & & \\
\hline
\end{tabular}

velocity ( $\mathrm{v}, \mathrm{m} /$ day), conductivity of aquifer (ca, m/day), primary effective porosity $\left(\mathrm{pp}, \mathrm{m}^{3} / \mathrm{m}^{3}\right)$, and hydraulic gradient $(\mathrm{h}, \mathrm{m} / \mathrm{m})$ as (Wendland 1992):

$v=\frac{(\mathrm{ca} \times h)}{\mathrm{pp}}$

Wendland (1992) provided empirical average values of primary effective porosity and conductivity of aquifers. Average shallow groundwater residence time was estimated as:

$\mathrm{RT}_{\mathrm{sgw}}=\frac{\mathrm{lp}}{(v+360)}$

where $\mathrm{RT}_{\mathrm{sgw}}$ is the average shallow groundwater residence time (year), $1 p$ is the average length of underground flow path (m), and 360 is a conversion factor (days per year). The distance parameter can be estimated as a function of the stream density:

$\mathrm{lp}=\frac{1000}{2 \times \mathrm{ns}}$

where $\mathrm{ns}$ is the number of streams per $\mathrm{km}^{2}$ and 1000 is a conversion factor from kilometers to meters. If there is no stream density map, "ns" can be estimated as:

$\mathrm{ns}=$ if $\left[\right.$ water, then, 2, else $\left.\left(\frac{Q}{450}\right)^{0.8}\right]$.
The final part of water fluxes as shown in Fig. 2 is the deep groundwater residence time, and it was estimated as:

$\mathrm{RT}_{\mathrm{dgw}}=\frac{1000 \times \mathrm{tp} \times \text { at }}{f_{\mathrm{dgw}}}$

where $\mathrm{RT}_{\mathrm{dgw}}$ is the average deep groundwater residence time (year), tp is the total effective aquifer porosity $\left(\mathrm{m}^{3} /\right.$ $\left.\mathrm{m}^{3}\right)$, at is the aquifer thickness $(\mathrm{m}), f_{\mathrm{dgw}}$ is the long-term average deep groundwater recharge ( $\mathrm{mm} /$ year), and 1000 is a conversion factor ( $\mathrm{mm}$ to $\mathrm{m}$ ).

\section{Water demand estimation}

The total water demand in the Pra Basin comprises domestic water demand, industrial water demand, and agricultural water demand. Domestic water demand was estimated as:

$D_{\text {dom }}=\frac{P_{\text {district }} \times \text { percapita } \times 365}{1000}$

where $D_{\text {dom }}$ is annual domestic water demand ( $\mathrm{m}^{3} /$ year), $P_{\text {district }}$ is annual population of a district, and per capita is per capita water demand (liters/capita/day). The numbers 365 and 1000 are to convert it from day to year and liters to $\mathrm{m}^{3}$, respectively. Average per capita water demand in the Pra Basin has been estimated by Opoku-Ankomah (2000) to be $65 \mathrm{l} / \mathrm{c} / \mathrm{d}$.

There are limited lumped data on industrial water demand in the basin. The data on large-scale industrial water demand (Table 3) were extracted from EPA (2000). All the large annual-scale industrial water demand was computed by multiplying the demand by 310 working days. Smallscale industries, however, are common in the basin, but there were no data on them. Small-scale water demand was estimated based on the proportion of the working population in the industries (Table 5). In developing countries, it has been estimated that $4.3 \%$ of water use is industrial as 
Table 3 Major industries and their water demand in the Pra Basin (EPA 2000)

\begin{tabular}{llc}
\hline Industry & Town & $\begin{array}{l}\text { Demand/use }\left(\mathrm{m}^{3} /\right. \\
\text { year) }\end{array}$ \\
\hline Guinness Ghana limited & Kumasi & 72,000 \\
Kumasi Brewery limited (KBL) & Kumasi & 4515 \\
Ashanti Goldfields Corporation & Obuasi & 9300 \\
Dunkwa Continental Gold mines & Konongo & 9300 \\
AGC & Anyanfuri & 9300 \\
Midras minings & Kibi & 9300 \\
Obenemasi Gold mines & Konongo & 9300 \\
Ghana Consolidated Diamond & Akwatia & 9300 \\
limited & & \\
\hline
\end{tabular}

Table 4 Irrigation water demand (EPA 2000)

\begin{tabular}{lrl}
\hline Site & Area $(\mathrm{Ha})$ & Demand $\left(\right.$ million $\left.\mathrm{m}^{3}\right)$ \\
\hline Komenda & 2000 & 84 \\
Nobewam & 80 & 3.36 \\
Adiembra & 96 & 3.84 \\
\hline
\end{tabular}

against $12.6 \%$ for domestic (Wada 2008). Therefore, industrial water demand at district level was estimated as:

$D_{\text {industry }}=311 \frac{A}{4.3} \times 0.34 \frac{D_{\text {dom }}}{365}$

where $D_{\text {industry }}$ is small-scale industrial demand in a year (311 working days), A is average proportion of industrial economic activities in a district (computed from Table 5), 4.3 is percentage of industrial water use in developing countries (Wada 2008), 0.34 is the ratio between industrial water use in developing countries $(4.3 \%)$ and domestic water use $(12.6 \%)$.

Agricultural water demand consists of livestock water demand and irrigation water demand. There were no data on livestock water demand, and it was estimated based on $6 \%$ of rural water demand as (Water-Resources-Commission 2012):

Demand $_{\text {livestock }}=0.06 \times$ Demand $_{\text {rural }}$

Demand $_{\text {rural }}=\frac{P_{\text {rural }} \times \text { percapita } \times 365}{1000}$

where $P_{\text {rural }}$ is population of rural areas in each district. Large-scale irrigation water demand data were abstracted from EPA (2000). The main irrigation dams and their water demand are listed in Table 4. "Informal urban and peri urban irrigation is practiced around some towns in the basin. There is little data on the overall extent of this informal irrigation in the basin. However, it is estimated that there are at least 12,700 smallholders irrigating more than 11,900 ha in the dry season around Kumasi [Metropolitan Assembly] alone, which is more than the area currently functioning under formal irrigation in the whole of the country." (Water-Resources-Commission 2012). Just like industrial water demand, informal irrigation water demand was estimated as:

$D_{\text {irrigation }}=311 \frac{A}{83} \times 19 \frac{D_{\text {dom }}}{365}$

where $D_{\text {irrigation }}$ is an informal irrigation water demand in a year (311 working days), $\mathrm{A}$ is an average proportion of agricultural activities in a district (computed from Table 5), 83 is percentage of agricultural water use in developing countries (Wada 2008), 19 is the ratio between agricultural water use in developing countries $(83.1 \%)$ and domestic water use $(12.6 \%)$.

The total water demand is the summation of domestic, industrial, and agricultural water demand:

$$
\begin{aligned}
\text { Demand }= & \text { Demand }_{\text {domestic }}+\text { demand }_{\text {industrial }} \\
& + \text { demand }_{\text {livestock }}+\text { demand }_{\text {irrigation }}
\end{aligned}
$$

\section{Water stress estimation}

Water stress was computed based on the scenario that all the demand will be met by surface water only (Eq. 20), groundwater only (Eq. 21), and from both surface and groundwater (Eq. 22).

$$
\begin{aligned}
& \mathrm{Vul}_{\mathrm{RS}}=\frac{\text { Demand }}{R_{\mathrm{S}}} \\
& \mathrm{Vul}_{\text {Rgw }}=\frac{\text { Demand }}{R_{\mathrm{gw}}} \\
& \mathrm{Vul}_{\text {total }}=\frac{\text { Demand }}{Q} .
\end{aligned}
$$

\section{The 2050 scenario analyses}

The model also simulated 2050 water stress based on the following scenarios:

- There is a climate change with a decrease in precipitation relative to historical data and referred to as "drier", i.e., a $10 \%$ reduction in precipitation relative to the reference situation was applied.

- There is a climate change with an increase in precipitation relative to historical data and referred to as "wetter". In this case, a $10 \%$ increase in precipitation relative to the reference.

- There is a climate change with $1{ }^{\circ} \mathrm{C}$ increase in temperature.

For each scenario, the population of the district is computed based on the growth rate as 


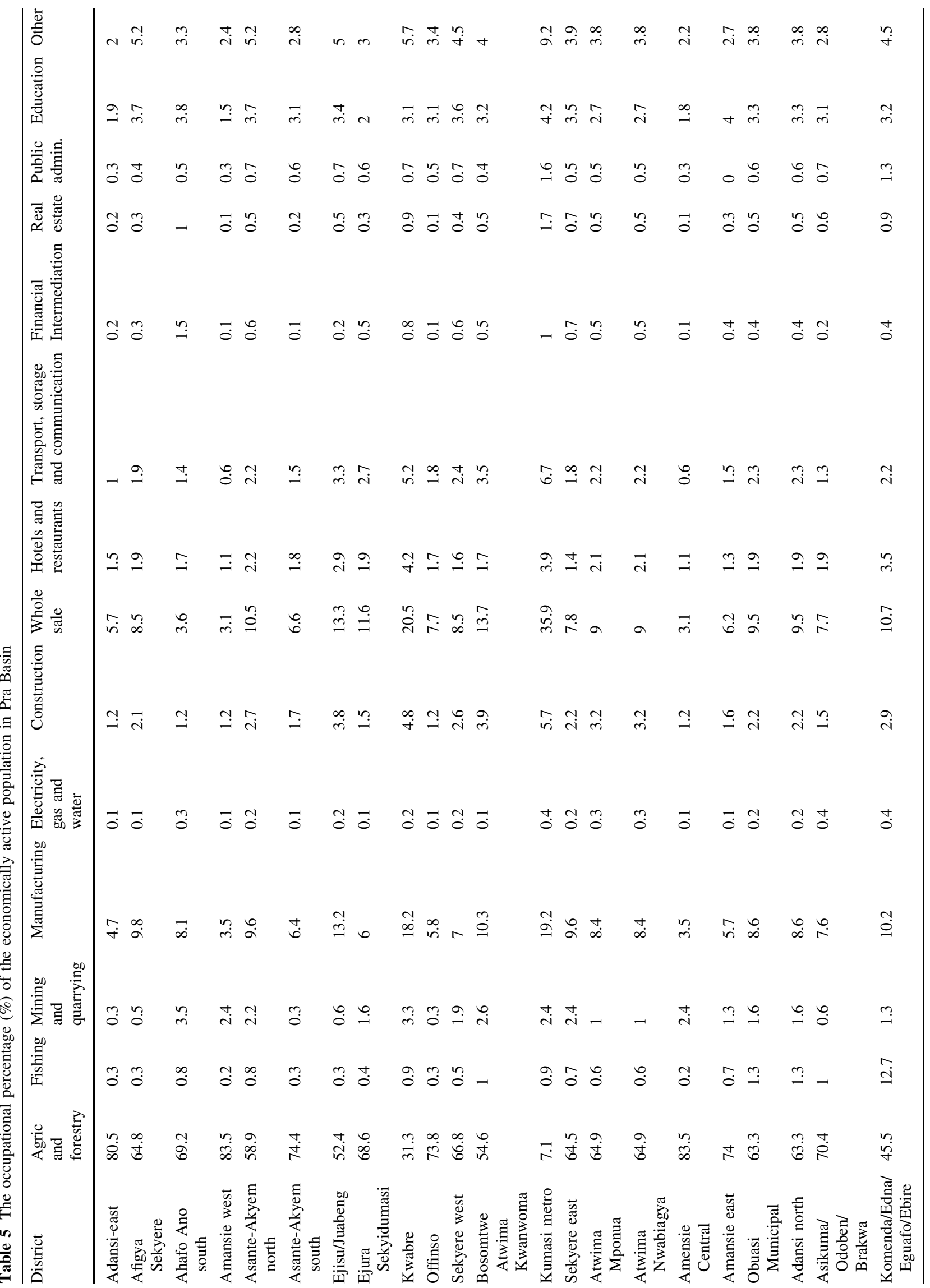




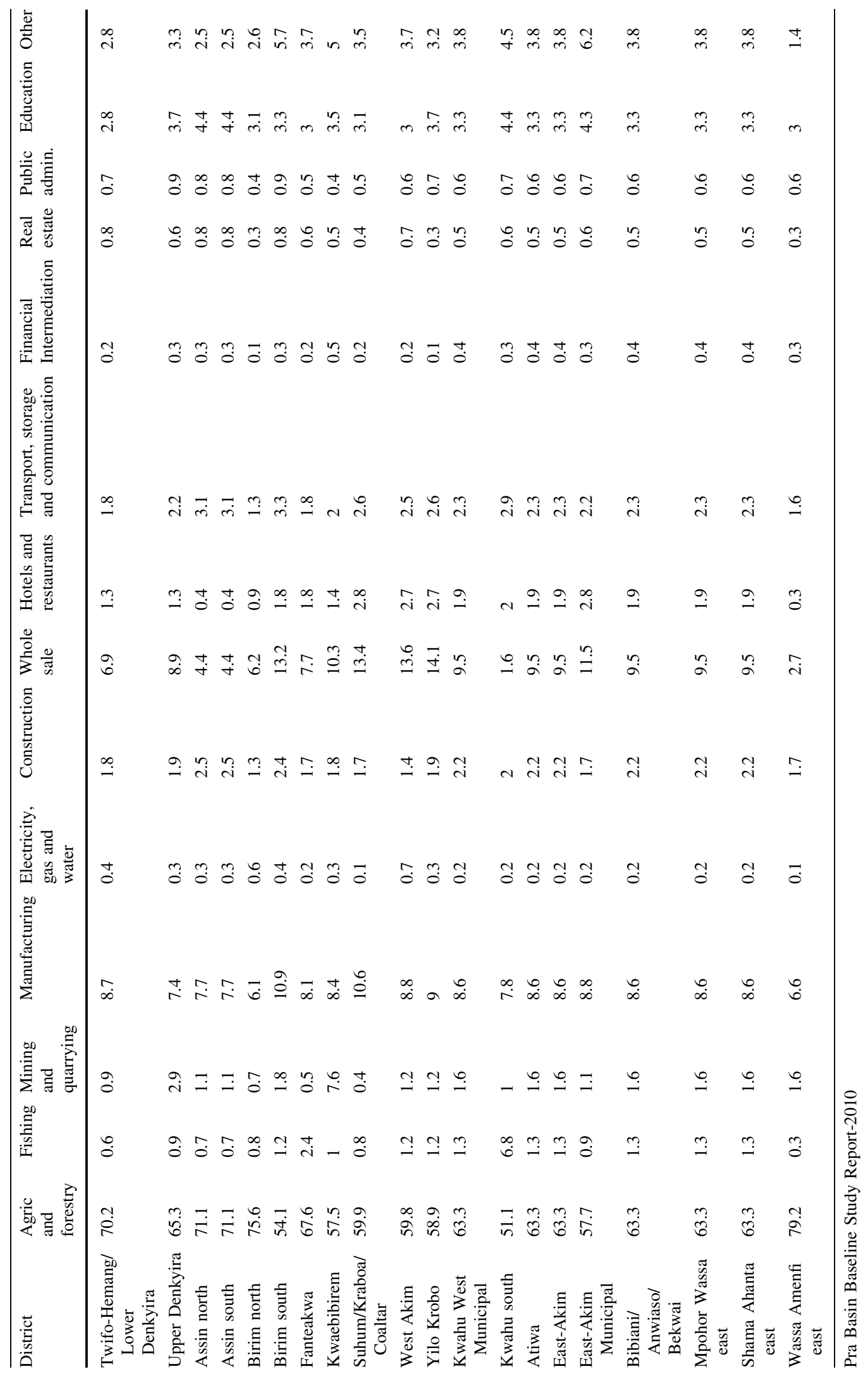


$R_{i}=\left(\frac{\left(P_{2010 i j}-P_{1995 i}\right) / P_{1995 i}}{n}\right)$

where $R$ is percentage growth rate for each district $(i), P$ is the population of a district, and $\mathrm{n}$ is the difference between the years 2010 and $1995(n=15$ years)

The 2050 projected population $\left(P_{2050}\right)$ status for each district was then estimated as:

$P_{2050}=P_{1995} e^{R_{i} t}$

where $R_{i} t$ is growth rate for each district over time, e is natural $\log$.

\section{Input data}

The data for the model were retrieved from Ghana Hydrological Services, Meteorological Services of Ghana, Water Resources Commission of Ghana, and Districts and Municipal assemblies. The data from "Ghana at glance" also provided input variables such as land cover, soils, geology, and vegetation (Owusu 2014). The weather data were retrieved from three weather stations: Kumasi, Dunkwa, and Oda (Fig. 3). The SRTM DEM (NASA 2004) was used in this study (Table 6).

\section{Model output}

The model output includes the following maps:

1. Long-term average total runoff.

2. Groundwater recharge indices.

3. Groundwater residence time.

4. Water demand.

5. Surface water Vulnerability index.

6. Groundwater Vulnerability index.

7. Total Vulnerability index.

\section{Model calibration and validation}

The POLFLOW model was calibrated and validated by dividing the weather and discharge data into two: 1990-1995 and 1996-2000. The long-term annual average of 1990-1995 data was used for calibration, while 1996-2000 was used for validation. The parameters were first optimized at calibration stage, and at the validation stage, the optimized parameters were used with the validation data. The POLFLOW model was calibrated by manually tuning aquifer index $\left(f_{\mathrm{dqw}}^{\mathrm{aq}}\right)$, primary porosity (pp), conductivity of the aquifer (ca), soil type index $\left(f_{\text {dqw }}^{\text {so }}\right)$, and land cover index $\left(f_{\mathrm{dqw}}^{\mathrm{lc}}\right)$, as shown in Tables 1 and 2. Several runs of the model were performed for the various combinations of the parameters. The optimized parameters' values are shown in Table 7. The soil and land cover map of the study areas are shown in Fig. 3. The estimated value of groundwater recharge was also compared with EPA (2000) values. The estimated water demand values were compared with Gyau and Adom (EPA 2000) estimation. The estimated water stress indices were compared with Opoku-Ankomah (2000) estimation.

\section{Evaluation of the model}

The performance of the hydrological model was statistically evaluated based on nine observed records at the following substations (Fig. 2):

- Outflow point at Deboase.

- Mfensi and Dunkwa hydro-stations on Offin tributary.

- Konongo and Anwia-Nkwanta on Oda tributary.

- Bunso and Akim Oda on Birim River.

- Assin-Praso and Twifo Praso on the main Pra River.

The statistical criteria of the evaluation were based on the analysis of residual errors, i.e., the difference between observed (measured) and simulated values. The normalized root mean square error (NRMSE) and the Nash-Sutcliffe model efficiency coefficient (NSE) (Nash and Sutcliffe 1970; Moriasi et al. 2007) were computed as:

$$
\begin{aligned}
& \text { NRMSE }=\frac{\sqrt{\frac{1}{n} \sum_{i=1}^{n} S_{i}-O_{i}}}{O_{\max }-O_{\min }} \\
& \mathrm{NSE}=1-\left[\frac{\sum_{i=1}^{n}\left(O_{i}-S_{i}\right)^{2}}{\sum_{i=1}^{n}\left(O_{i}-O^{\text {mean }}\right)^{2}}\right]
\end{aligned}
$$

while $S$ is simulated and $O$ is observed for station $i, O_{\max }$ and $O_{\text {min }}$ are the maximum and minimum observed values, respectively, and $O^{\text {mean }}$ is the mean of observed data. NSE "Values between 0.0 and 1.0 are generally viewed as acceptable levels of performance, whereas values $<0.0$ indicates that the mean observed value is a better predictor than the simulated value, which indicates unacceptable performance" (Moriasi et al. 2007).

\section{Results}

\section{Modeled versus measured discharge}

The model estimated a long-term annual discharge of Pra river at the outflow point at Deboase station to be $198.187 \mathrm{~m}^{3} / \mathrm{s}$ as against long-term average measurement 


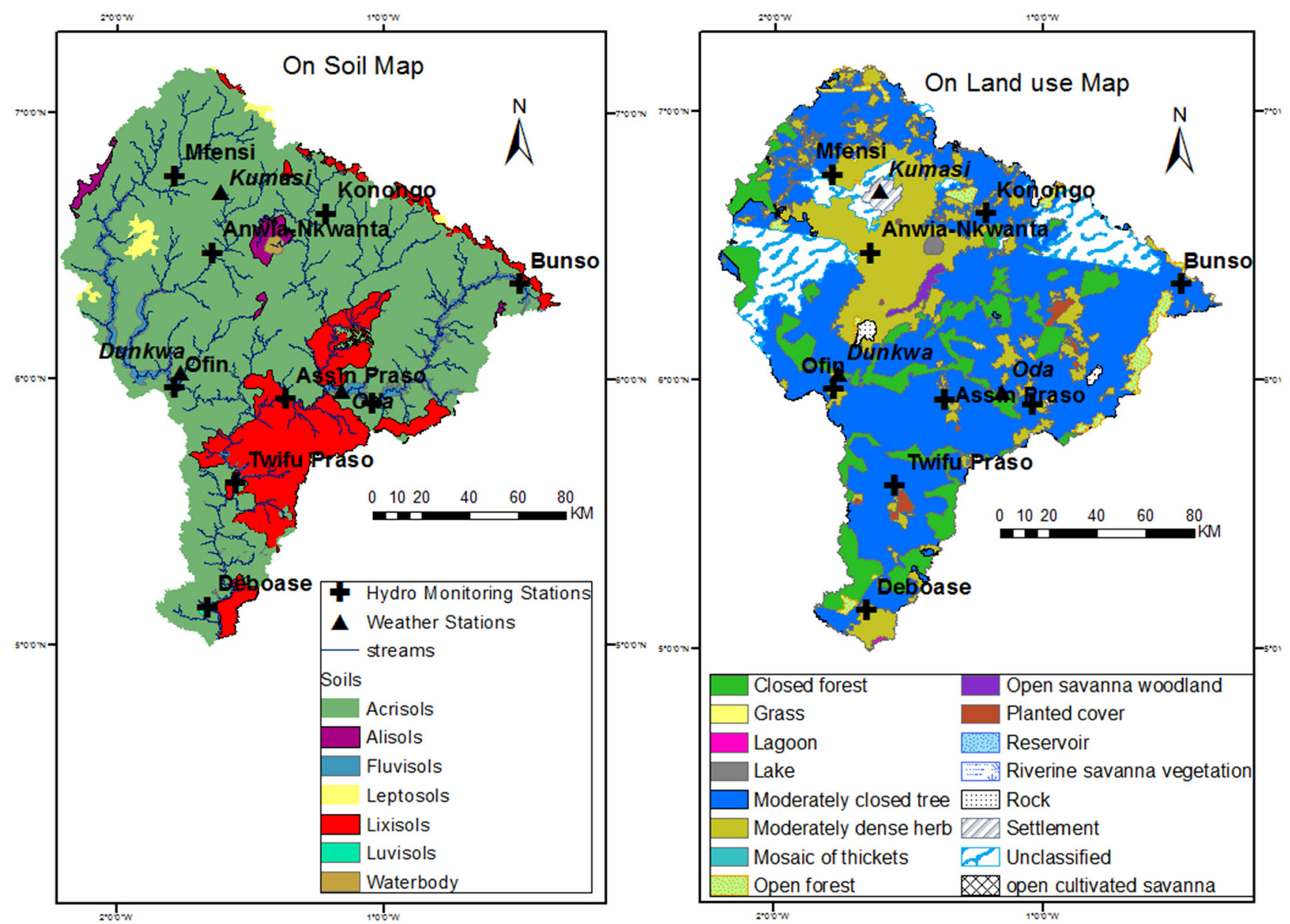

Fig. 3 The soil and land cover maps of Pra Basin showing the overlay of hydrological and meteorological Stations

Table 6 Sources of data for the model

\begin{tabular}{|c|c|c|c|}
\hline Data & Spatial resolution & Temporal resolution & Sources \\
\hline Average annual precipitation & - & $1990-2000$ & Ghana Meteorological Service \\
\hline Average annual temperature & - & $1990-2000$ & Ghana Meteorological Service \\
\hline Average annual evapotranspiration & - & $1990-2000$ & Ghana Meteorological Service \\
\hline Geology & $1: 1,000,000$ & - & EPA, Ghana geological Survey \\
\hline Hydrogeological map & $1: 2,000,000$ & 2000 & EPA (2000) \\
\hline Digital elevation model (DEM) & $90 \mathrm{~m}$ & 2004 & USGS-SRTM \\
\hline Slope & $90 \mathrm{~m}$ & - & Derived from DEM \\
\hline River network & $90 \mathrm{~m}$ & - & Derived from DEM \\
\hline Catchment boundary & $90 \mathrm{~m}$ & - & Derived from DEM \\
\hline Land cover & $30 \mathrm{~m}$ & $1990-2000$ & CERSGIS/Ghana at Glance \\
\hline Soil map & $1: 250,000$ & $1990-2000$ & Soil Research \\
\hline District boundaries & - & - & Lands Commission \\
\hline Regional boundaries & - & - & Lands Commission \\
\hline Discharge data & - & $1990-2000$ & $\begin{array}{l}\text { Hydrological Services Dept } \\
\text { Water Resources Commission }\end{array}$ \\
\hline Population & District & 1995,2010 & Statistical service \\
\hline Reservoir & - & - & Water Resources Commission \\
\hline Livestock & - & 2000 & Statistical service \\
\hline
\end{tabular}


of $197 \mathrm{~m}^{3} / \mathrm{s}$ based on optimized parameters in Table 7 . In addition, model estimates are also available for upstream and downstream of each tributary: A discharge of 9.95 and $71.01 \mathrm{~m}^{3} / \mathrm{s}$ was estimated at Mfensi and Dunkwa hydro-stations on Offin tributary as against 10.3 and $76.2 \mathrm{~m}^{3} / \mathrm{s}$ that were measured, respectively. The model estimates were 3.53 and $9.7 \mathrm{~m}^{3} / \mathrm{s}$ for Konongo and Anwia-Nkwanta on the Oda tributary as against the 4.3 and $8.5 \mathrm{~m}^{3} / \mathrm{s}$ that were measured, respectively. On the Birim tributary, the model estimates were $3.04 \mathrm{~m}^{3} / \mathrm{s}$ upstream and $35.35 \mathrm{~m}^{3} / \mathrm{s}$ downstream as against 3.7 and $43.4 \mathrm{~m}^{3} / \mathrm{s}$ that were measured for Bunso and Akim Oda stations, respectively. On the Pra main River, the model estimates were $88.1 \mathrm{~m}^{3} / \mathrm{s}$ upstream and $153 \mathrm{~m}^{3} / \mathrm{s}$ downstream as against 83.6 and $179.05 \mathrm{~m}^{3} / \mathrm{s}$ that were measured for Assin-Praso and Twifu Praso stations, respectively. Figure 4 shows the relationship between modeled and measured discharge at nine substations in the basin. The normalized root mean square error (RMSE) was $1.6 \%$, and Nash-Sutcliffe model efficiency coefficient was 0.98 for the calibrated model. At the validation stage, the root mean square error (RMSE) was $2.5 \%$, while Nash-Sutcliffe model efficiency coefficient was 0.93 ; this indicates that the model estimation is in agreement with the longterm measured discharge.

\section{Modeled total runoff, quick runoff, and total groundwater recharge}

Figure 5 shows the estimated total runoff (Eq. 1), quick runoff (Eq. 6), total groundwater recharge (Eq. 5), and deep groundwater recharge of the basin. The groundwater recharge rates, just like the total runoff and quick runoff, tend to be lower in the northern part of the catchment. The estimated minimum, average, and maximum total runoff for the Pra Basin is 175.88, 297.87, and $489.46 \mathrm{~mm} / \mathrm{year}$, respectively. The estimated average quick runoff, total groundwater recharge, and deep groundwater recharge for the basin is $97.60,200.27$, and $85.15 \mathrm{~mm} / \mathrm{year}$, respectively.

\section{Estimated groundwater recharge indices and groundwater residence times}

The estimated minimum, average, and maximum total recharge index for Pra Basin was, respectively, 20, 67, and $99 \%$ of water surplus (Eq. 1), leaving the average quick runoff coefficient to be $33 \%$ of the water surplus (Fig. 6). Spatially, the proportion of water surplus (Eq. 1) that is available for groundwater recharge ranges mainly from 60 to $100 \%$ in the lowland gentle slope areas (Fig. 6). The

Table 7 The values of the optimized parameters of the recharge model

\begin{tabular}{|c|c|c|c|c|c|c|c|c|c|}
\hline Soil type & $f_{\mathrm{dqw}}^{\mathrm{so}}$ & Land cover & $f_{\mathrm{dqw}}^{\mathrm{lc}}$ & Aquifer type & $f_{\mathrm{dqw}}^{\mathrm{aq}}$ & $\mathrm{pp}$ & $\mathrm{ca}$ & Soil & fsodgw \\
\hline Sand & 0.95 & Open Forest & 1.00 & $\begin{array}{l}\text { Birimian volcanics (Metamorphosed Lava and } \\
\text { Pyroclastic Rock and Hypabyssal Basic Intrusive, } \\
\text { Phyllite and Greywacke) }\end{array}$ & 0.50 & 0.15 & 17 & Leptosols & 0.95 \\
\hline Sandy Loam & 0.75 & $\begin{array}{l}\text { Open cultivated } \\
\text { savanna } \\
\text { woodland }\end{array}$ & 0.92 & Dahomeyan (Granite) & 0.55 & 0.15 & 17 & Fluvisols & 0.75 \\
\hline Loam & 0.50 & $\begin{array}{l}\text { Savanna } \\
\text { woodland }\end{array}$ & 0.92 & $\begin{array}{l}\text { Birimian Sediments (Phyllite, Schist, Tuff \& } \\
\text { Greywacke) }\end{array}$ & 0.50 & 0.15 & 30 & Lixisols & 0.95 \\
\hline Clay Loam & 0.25 & Settlement & 0.40 & $\begin{array}{l}\text { Tarkwaian (Quartzite, Phyllite, Grit, Conglomerate and } \\
\text { Schist, including basic intrusive) }\end{array}$ & 0.50 & 0.15 & 17 & Luvisols & 0.75 \\
\hline Clay & 0.05 & $\begin{array}{l}\text { Reservoir \& } \\
\text { Lake }\end{array}$ & 0.000001 & Upper Voltaian (Mainly Sandstone) & 0.50 & 0.15 & 30 & Gleysols & 0.95 \\
\hline \multirow[t]{6}{*}{$\begin{array}{l}\text { Groundwater } \\
\text { near surface }\end{array}$} & 0.10 & $\begin{array}{l}\text { Riverine } \\
\text { savanna } \\
\text { vegetation }\end{array}$ & 0.92 & $\begin{array}{l}\text { Sekondian (Sandstone, Grit, Conglomerate, Shale and } \\
\text { Mudstones, Nodules of Limestone and Siderite) }\end{array}$ & 0.50 & 0.15 & 30 & Vertisols & 0.25 \\
\hline & & Scattered trees & 0.92 & & & & & Arenosols & 0.75 \\
\hline & & & & & & & & Acrisols & 0.05 \\
\hline & & & & & & & & Nitosols & 0.05 \\
\hline & & & & & & & & Alisols & 0.05 \\
\hline & & & & & & & & Solonetz & 0.25 \\
\hline
\end{tabular}




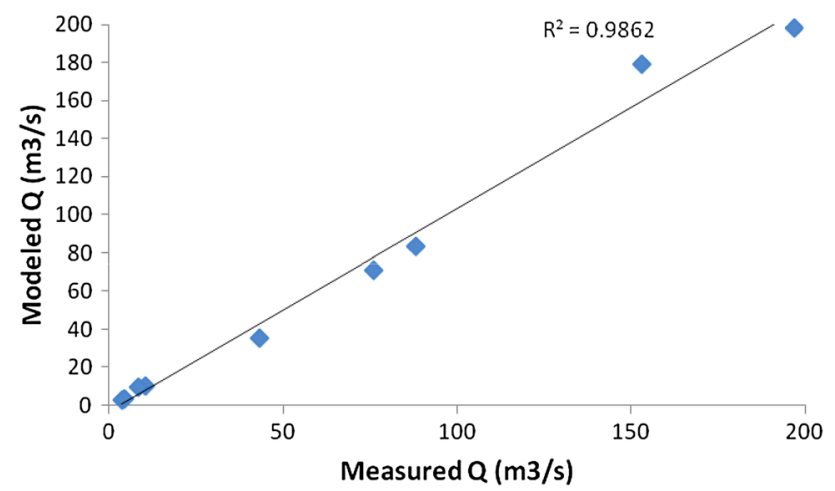

Fig. 4 Modeled versus measured annual average discharge $\left(\mathrm{m}^{3} / \mathrm{s}\right)$ of 9 hydro substations of Pra Basin

estimated minimum, average, and maximum deep groundwater recharge index for the Pra Basin is, respectively, 0,28 , and $52 \%$ of water surplus (Fig. 6). The average shallow groundwater residence time is 1.23 years, while the average deep water residence time is 125 years. The shallow groundwater residence time (Eq. 10), the time it takes for water to join an adjacent stream, is mainly less than 2 years, with a minimum of 0.0076 years (2.75 days), but deep groundwater residence time (Eq. 13) is predominately greater than 50 years (Fig. 6).

\section{Estimated and projected water demand}

Figure 7 shows spatiotemporal patterns of water demand in the Pra Basin. The estimated mean domestic water demand is 2,261,330 and 8,735,522 $\mathrm{m}^{3} /$ year for 2000 and 2050, respectively, while the total demand for the whole basin was estimated as $69,044,682$ and $262,787,260 \mathrm{~m}^{3} /$ year for the years 2000 and 2050, respectively. The estimated mean industrial water demand is 5,893,501 and 22,504,958 $\mathrm{m}^{3} /$ year for 2000 and 2050, respectively. The total industrial water demand was estimated as $238,868,171$ and $860,864,391 \mathrm{~m}^{3} /$ year for the years 2000 and 2050, respectively.

The results suggest that there is a possibility of a significant increase in industrial water demand $(p=0.0016)$ by the year 2050 . The estimated mean agricultural water
Fig. 5 The average estimated runoff ( $\mathrm{mm} /$ year) and groundwater recharge $(\mathrm{mm} /$ year) of Pra Basin

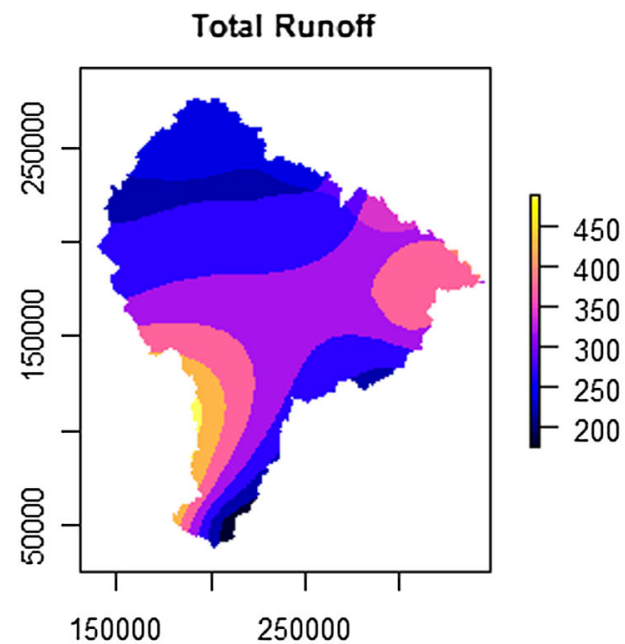

Total Groundwater Recharge

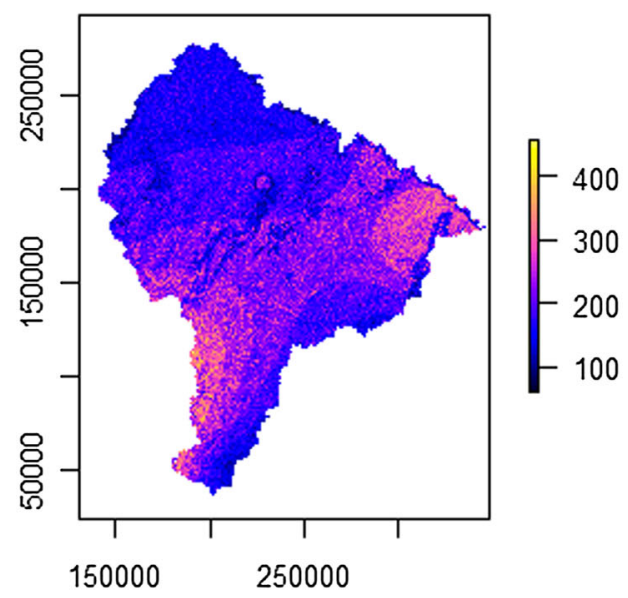

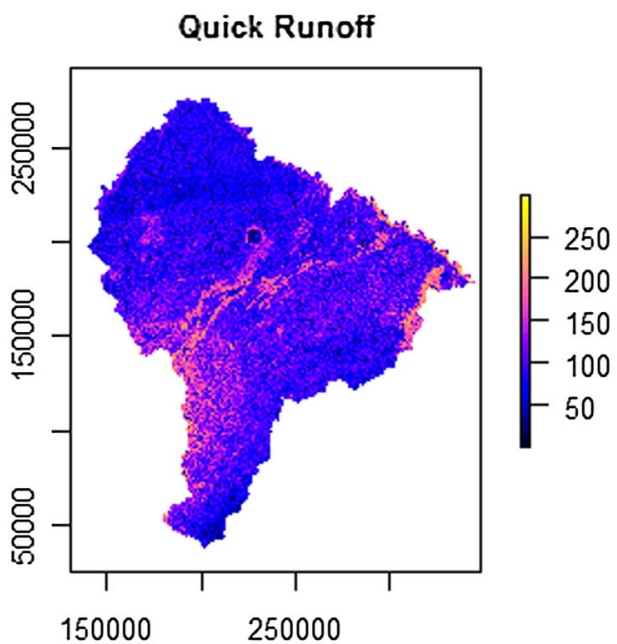

Deep Groundwater Recharge

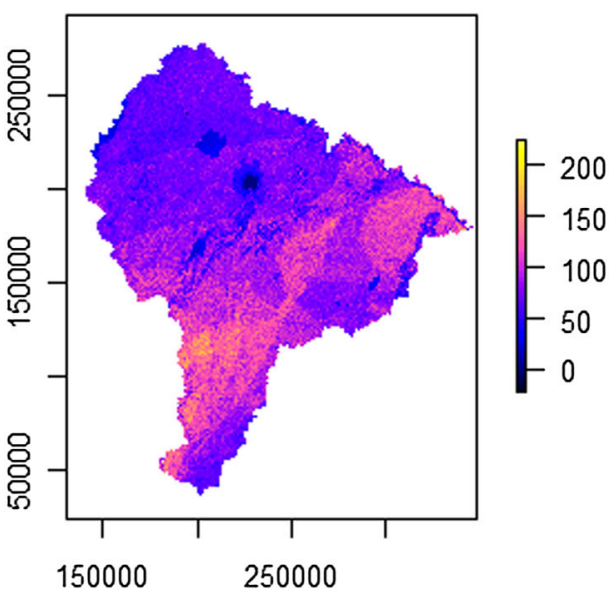


Fig. 6 The estimated groundwater recharge indices $(-)$ and groundwater residence times (years) of Pra Basin. Note: the light tone colors (yellow) for shallow groundwater and deep groundwater are higher than 2 and 250 years, respectively
Total Groundwater Recharge index

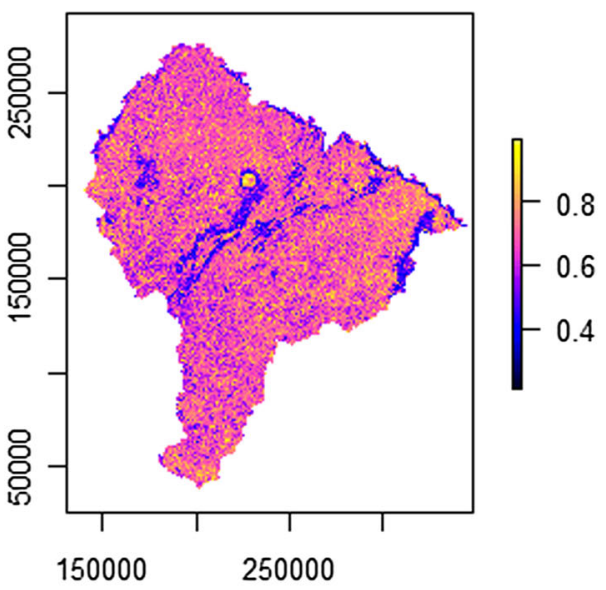

Shallow Groundwater Residence Time

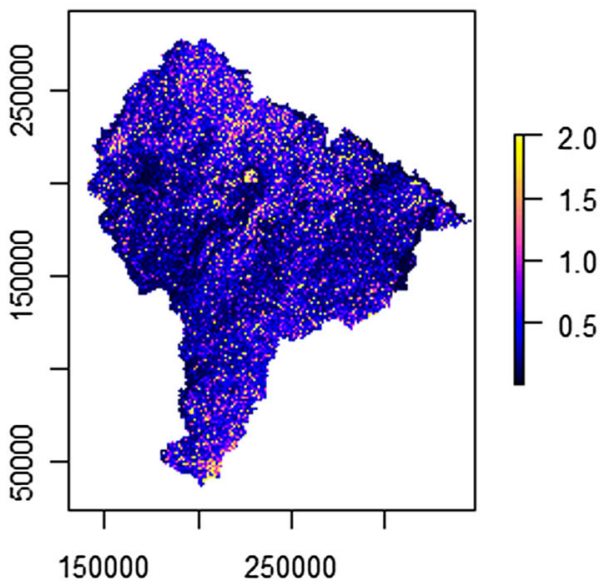

Deep Groundwater Recharge Index

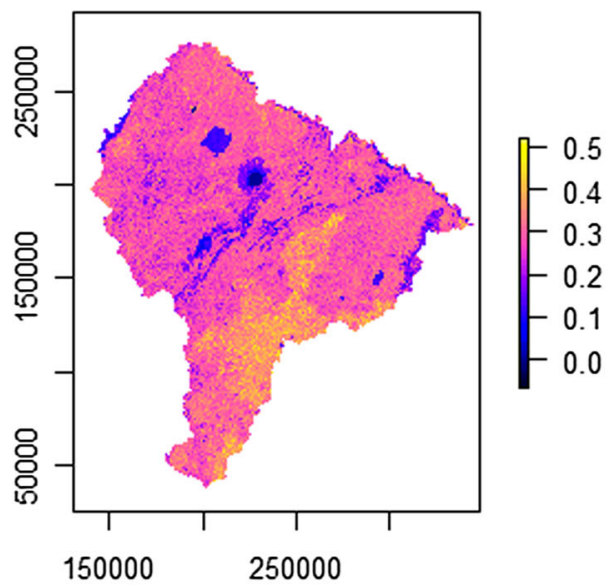

Deep Groundwater Residence Time

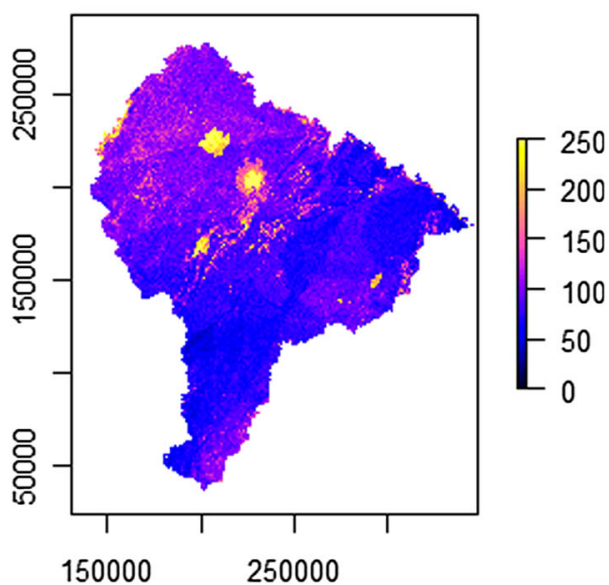

demand was 26,957,279 and 105,086,000 $\mathrm{m}^{3} /$ year for 2000 and 2050, respectively. The total agricultural water demand was estimated as 651,136,235,000 and $2,625,907,368,000 \mathrm{~m}^{3} /$ year for the years 2000 and 2050 , respectively. The analysis showed that by the year 2050 , there will be a significant increase in agricultural water demand ( $p=0.0003)$. The highest domestic and industrial water demand occurred at Kumasi Metropolitan Area, in the northern part of the basin.

\section{Water stress}

The average surface water stress Index was estimated as 0.0385 and 0.150 for the years 2000 and 2050, respectively, and the difference is significant ( $p=0.00043)$. The average groundwater stress was estimated as 0.055 and 0.15 , and the difference is significant ( $p=0.00044)$. There is, however, high spatial distribution of water stress in both years with some areas such as Kumasi Metropolitan Area and Kwabre districts registering maximum index of 1, i.e., more areas are likely to experience higher water stress in 2050.

\section{Discussions}

The study estimated water stress based on stream and groundwater discharge and water demand. The discharge estimation was in agreement with the measured discharge, with Nash-Sutcliffe model efficiency coefficient of 0.98 . The high accuracy of the modeled discharge may be due to a slight modification in computation of discharge. Thus, whereas other POLFLOW researchers (De Wit 2001; Jarsjö et al. 2004; Durdu 2005) simulated the accumulated discharge of Eq. 1 with the measured discharge, this study divided the accumulated discharge in Eq. 1 into quick runoff and delayed runoff (Shallow and Deep groundwater), and only delayed runoff with a residence time less than or equal to 1 year was accumulated with the quick runoff to simulate total river discharge. This approach 
Fig. 7 Estimated and projected water demand $\left(\mathrm{m}^{3} /\right.$ year) of Pra Basin

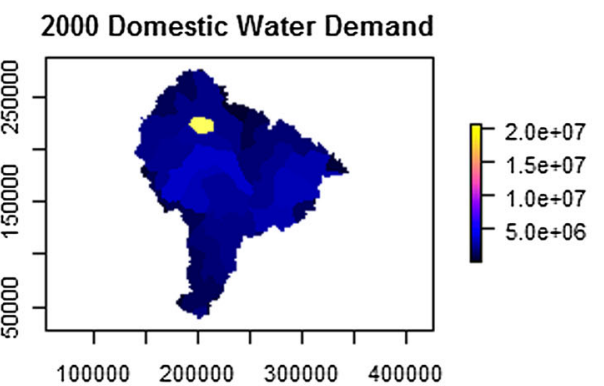

2000 Industrial Water Demand
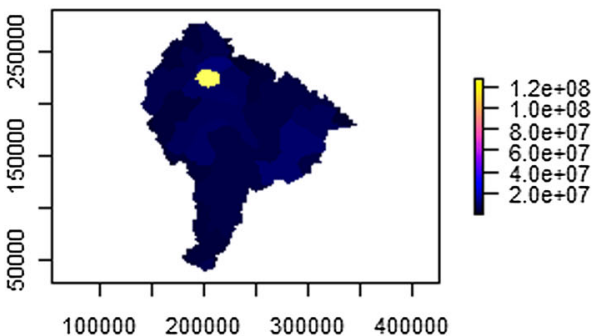

2000 Agric Water Demand

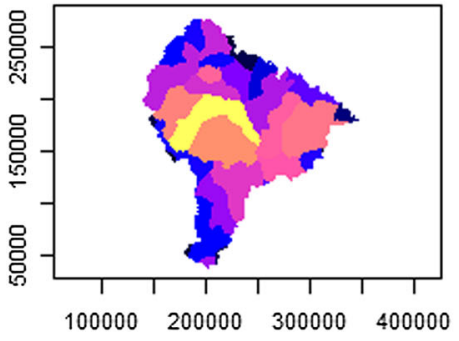

2050 Domestic Water Demand

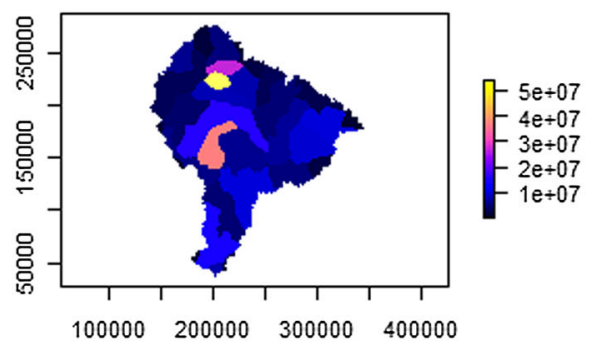

2050 Industrial Water Demand

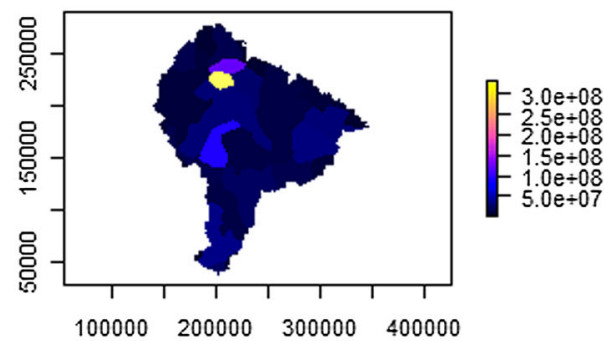

2050 Agric Water Demand

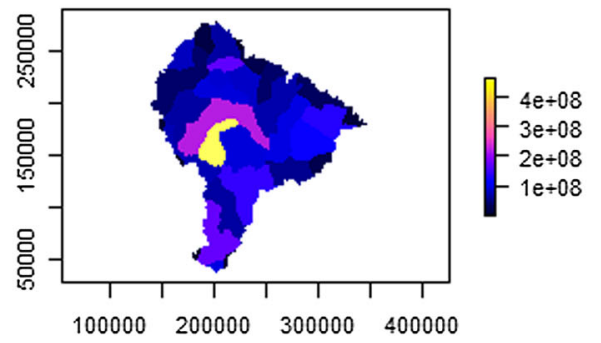

Table 8 Ranges and interpretation of water stress indices (Kundzewicz et al. 2007; Wada 2008)

\begin{tabular}{llll}
\hline Degrees of water stress & Per capita water availability & Water scarcity index Rws $(-)$ & Definitions of degrees of water stress \\
\hline No stress & $>1700$ & Rws $<0.1$ & No water stress \\
Low stress & - & $0.1<\mathrm{Rws}<0.2$ & Potential water scarcity \\
Moderate stress & $1700-1000$ & $0.2<\mathrm{Rws}<0.4$ & Looming water scarcity \\
High stress & $1000-500$ & $0.4<\mathrm{Rws}<0.8$ & Experiencing water scarcity \\
Very high stress & $<500$ & $0.8<\mathrm{Rws}$ & Economic development is limited by water scarcity \\
\hline
\end{tabular}

helped in the calibration of velocity, conductivity, soil characteristic, and aquifer characteristics as in Eqs. (7-13) (Table 7).

The estimated mean daily groundwater recharge of $0.548 \mathrm{~mm} /$ day in this study is slightly higher than what WatBal lumped model estimated as $0.456 \mathrm{~mm} /$ day (EPA 2000). This may be due to the fact that this study used higher rainfall values with a mean of $1300 \mathrm{~mm} / \mathrm{year}$, while WatBal used only $1099.80 \mathrm{~mm} /$ year for the whole basin (EPA 2000). It must be emphasized that this study developed a distributed model with different rainfall values for 12 zones with minimum and maximum values as 1050 and $2150 \mathrm{~mm} /$ year, respectively.
The potency of this study in assessment of water stress depends on an accurate estimation of domestic water demand because industrial water demand is also related to it (Eqs. 14, 15) (Wada 2008). While Gyau and Adom (EPA 2000) estimated domestic water demand of the Pra Basin to be $193,651 \mathrm{~m}^{3} /$ day in 2000 and $871,829 \mathrm{~m}^{3} /$ day in 2050 , this study similarly estimated 189,164 and $719,965 \mathrm{~m}^{3} /$ day for the years 2000 and 2050, respectively. The values of the previous study appear a bit higher than this study because they used a per capita water demand as low as 30 liters/per capita/day for small communities to as high as $130 \mathrm{l} / \mathrm{per}$ capita/day for large communities. This study used a constant per capita value of $651 /$ per capita/day. Based on this 
Table 9 Water stress indices of the districts in Pra Basin

\begin{tabular}{|c|c|c|c|c|c|c|}
\hline \multirow{2}{*}{$\begin{array}{l}\text { District } \\
\text { Year }\end{array}$} & \multicolumn{2}{|c|}{ Surface water } & \multicolumn{2}{|c|}{ Groundwater } & \multicolumn{2}{|c|}{ Total water } \\
\hline & 2000 & 2050 & 2000 & 2050 & 2000 & 2050 \\
\hline Kumasi metro & 1.00 & 1.00 & 1.00 & 1.00 & 1.00 & 1.00 \\
\hline Asikuma/Odoben/Brakwa & 1.00 & 1.00 & 1.00 & 1.00 & 1.00 & 1.00 \\
\hline Komenda/Edna/Eguafo/Ebire & 1.00 & 1.00 & 1.00 & 1.00 & 0.64 & 1.00 \\
\hline Ejura Sekyidumasi & 0.73 & 1.00 & 1.00 & 1.00 & 0.46 & 1.00 \\
\hline Kwabre & 0.71 & 1.00 & 1.00 & 1.00 & 0.44 & 1.00 \\
\hline Suhum/Kraboa/Coaltar & 0.28 & 1.00 & 0.75 & 1.00 & 0.22 & 1.00 \\
\hline West Akim & 0.11 & 0.19 & 0.24 & 0.44 & 0.07 & 0.12 \\
\hline Sekyere west & 0.08 & 0.35 & 0.21 & 1.00 & 0.06 & 0.21 \\
\hline Bibiani/Anwiaso/Bekwai & 0.07 & 0.60 & 0.15 & 1.00 & 0.05 & 0.41 \\
\hline Wassa west & 0.07 & 0.36 & 0.14 & 0.74 & 0.05 & 0.25 \\
\hline Bosomtwe Atwima Kwanwoma & 0.07 & 0.34 & 0.12 & 0.70 & 0.04 & 0.19 \\
\hline Ejisu/Juabeng & 0.05 & 0.27 & 0.09 & 0.58 & 0.03 & 0.15 \\
\hline Kwahu south & 0.05 & 0.10 & 0.11 & 0.21 & 0.04 & 0.07 \\
\hline Ahafo Ano south & 0.03 & 0.28 & 0.06 & 0.62 & 0.02 & 0.17 \\
\hline Afigya Sekyere & 0.03 & 0.14 & 0.06 & 0.45 & 0.02 & 0.06 \\
\hline Offinso & 0.03 & 0.06 & 0.07 & 0.14 & 0.02 & 0.03 \\
\hline Sekyere east & 0.02 & 0.24 & 0.04 & 0.72 & 0.01 & 0.12 \\
\hline Wassa Amenfi east & 0.02 & 0.18 & 0.04 & 0.36 & 0.02 & 0.13 \\
\hline Obuasi Municipal (Adanse West) & 0.01 & 0.74 & 0.01 & 1.00 & 0.00 & 0.06 \\
\hline East-Akim & 0.01 & 0.07 & 0.03 & 0.14 & 0.01 & 0.05 \\
\hline Asante-Akyem north & 0.01 & 0.05 & 0.02 & 0.11 & 0.01 & 0.03 \\
\hline Kwaebibirem & 0.01 & 0.03 & 0.01 & 0.05 & 0.00 & 0.02 \\
\hline Fanteakwa & 0.01 & 0.03 & 0.03 & 0.07 & 0.01 & 0.02 \\
\hline Birim south & 0.01 & 0.01 & 0.01 & 0.02 & 0.00 & 0.01 \\
\hline Shama Ahanta east & 0.00 & 1.00 & 0.00 & 1.00 & 0.00 & 0.01 \\
\hline Mpohor Wassa east & 0.00 & 0.34 & 0.00 & 0.71 & 0.00 & 0.00 \\
\hline Upper Denkyira & 0.00 & 0.32 & 0.00 & 0.65 & 0.00 & 0.00 \\
\hline Twifo-Hemang/Lower Denkyira & 0.00 & 0.06 & 0.00 & 0.14 & 0.00 & 0.00 \\
\hline Atwima Nwabiagya & 0.00 & 0.05 & 0.00 & 0.12 & 0.00 & 0.00 \\
\hline Amansie east & 0.00 & 0.02 & 0.00 & 0.04 & 0.00 & 0.01 \\
\hline Asante-Akyem south & 0.00 & 0.01 & 0.00 & 0.02 & 0.00 & 0.00 \\
\hline Amansie west & 0.00 & 0.01 & 0.00 & 0.03 & 0.00 & 0.00 \\
\hline Assin (north) & 0.00 & 0.01 & 0.00 & 0.02 & 0.00 & 0.00 \\
\hline Birim north & 0.00 & 0.01 & 0.01 & 0.02 & 0.00 & 0.01 \\
\hline Adansi-east & 0.00 & 0.00 & 0.00 & 0.00 & 0.00 & 0.00 \\
\hline
\end{tabular}

Legend: Rws $<0.1=$ not stress; $0.1<$ Rws $<0.2=$ low stress, $0.2<$ Rws $<0.4=$ moderate stress; $0.4<$ Rws $<0.8=$ high stress; $0.8<$ Rws = very high stress (Wada 2008)

study, there is a possibility of a significant increase in domestic water demand $(p=0.0006)$, industrial water demand $(p=0.0016)$, and agricultural water demand ( $p=0.0003)$ by the year 2050 .

Surface water availability, groundwater availability, and total water stress were separately computed because of the water use pattern in the basin. Most of the smaller communities depend on groundwater boreholes, while the larger communities depend on surface water withdrawal. In this study, annual surface water estimation includes about $90 \%$ of shallow groundwater resources that have residence time less than or equal to 1 year. Therefore, without adding groundwater resources to compute total groundwater stress, the usage of surface water stress will be sufficient in accessing water stress in the basin. Using Kundzewicz et al. (2007) explanation of water stress indices (Table 8), three districts in the basin that include Kumasi Metro, Asikuma/ Odoben/Brakwa, and Komenda/Edna/Eguafo/Ebire 
Fig. 8 The estimated surface and total water stress indices (Rws) of Pra Basin. The total water stress indices were estimated by dividing total water demand by the sum of groundwater resources and surface water resources in the basin. Legend: Rws $<0.1=$ no stress; $0.1<$ Rws $<0.2=$ low stress,

$0.2<$ Rws $<0.4=$ moderate stress; $0.4<$ Rws $<0.8=$ high stress; $0.8<$ Rws $=$ very high stress (Wada 2008)
2000 Surface Water Stress

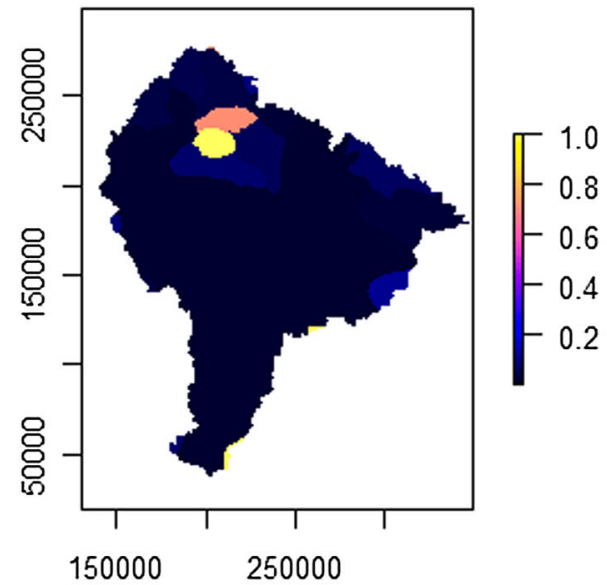

2000 Total Water Stress

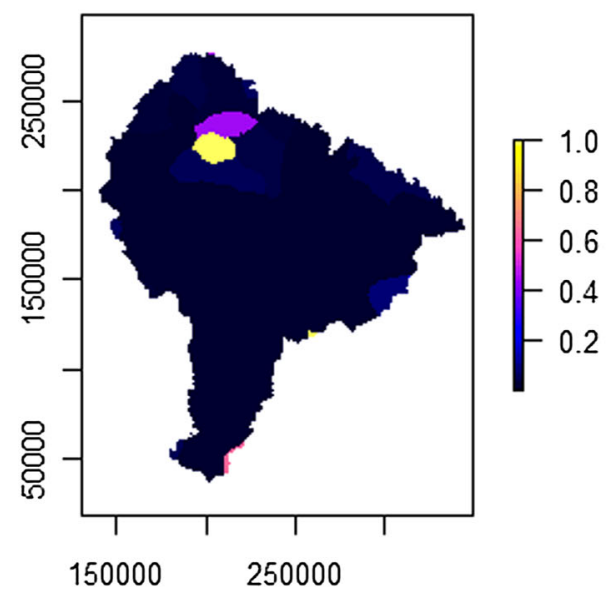

2050 Surface Water Stress

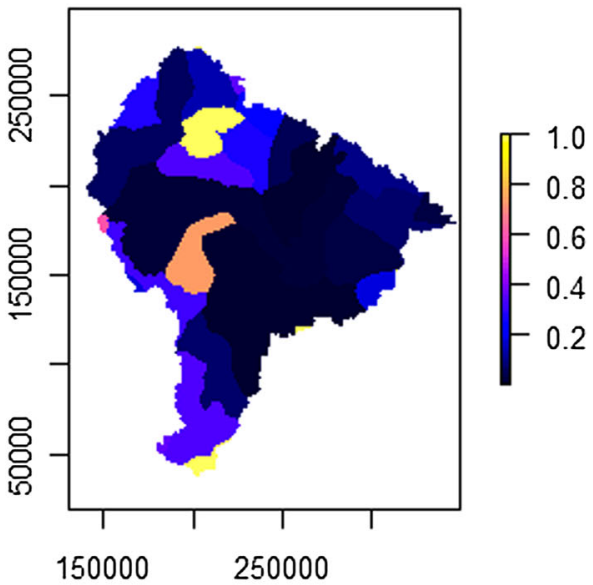

2050 Total Water Stress

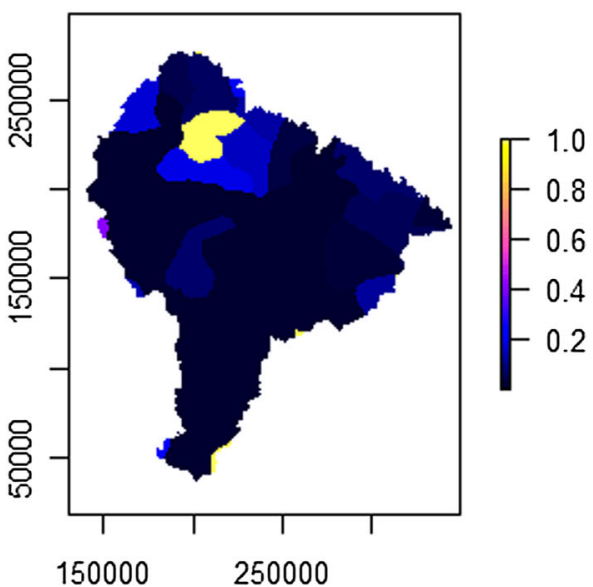

experienced very high surface water stress index of 1 . Other districts such as Ejura Sekyidumasi and Kwabre districts experienced high (0.4- 0.8) surface water stress, while Kwabre and Suhum/Kraboa/Coaltar experienced low to moderate surface water stress $(0.1-0.4)$. The rest of the districts experienced no water stress in the year 2000. The number of districts experiencing water stress will significantly increase ( $\mathrm{p}=0.00044$ ) from 8 in 2000 to 21 out of 35 districts in the basin by 2050 (Table 9; Fig. 8). Opoku-Ankomah (2000) used lumped model to estimate marginal vulnerability water stress for the whole basin in 2000 though he further added that it will be extremely vulnerable in 2050 .

\section{Conclusion}

The POLFLOW model has been mainly developed to estimate nutrient concentration in a catchment (De Wit 2001; Jarsjö et al. 2004; Durdu 2005). In this study, the
POLFLOW model has been adapted, modified and extended to estimate water availability, water demand, and water stress in the Pra Basin of Ghana. The estimated river discharge is in agreement with the measured discharge. The shallow and deep groundwater recharge and residence times were also estimated. Most of the shallow groundwater drains into the adjacent stream in less than 2 years, while it takes longer time for deep groundwater to join the streams. The total water demand estimation was divided into domestic, industrial, and agriculture. The estimated total water demand significantly increased from 2000 to 2050; therefore, the first null hypothesis which states that, "there will be no significant difference between the estimated water demand in 2000 and 2050," is rejected. The number of districts experiencing water stress will significantly increase from 8 in 2000 to 21 out of 35 districts by the year 2050; therefore, the second null hypothesis which states that "the number of districts experiencing water stress in the basin will not significantly differ in the years 2000 and 2050," is rejected. Though POLFLOW is 
mainly used to estimate nutrient concentration, this study has demonstrated that it can be modified to model water stress in the tropics.

Acknowledgments This research has been supported by the University of Ghana-Carnegie Next Generation of Academics in Africa project with funding from the Carnegie Corporation of New York.

Open Access This article is distributed under the terms of the Creative Commons Attribution License which permits any use, distribution, and reproduction in any medium, provided the original author(s) and the source are credited.

\section{References}

Alcamo J, Doll P, Henrichs T, Kaspar F, Lehner B, Rosch T, Siebert S (2003a) Development and testing of the WaterGAP 2 global model of water use and availability. Hydrol Sci J 48:317-338

Alcamo J, Doll P, Henrichs T, Kaspar F, Lehner B, Rosch T, Siebert S (2003b) Global estimation of water withdrawals and availability under current and "business as usual" conditions. Hydrol Sci J 48:339-348

Arnell NW (2003) Effects of IPCC SRES emissions scenarios on river runoff: a global perspective. Hydrology and Earth System Sciences 7

Baalousha HM (2012) Characterisation of groundwater-surface water interaction using field measurements and numerical modelling: a case study from the Ruataniwha Basin, Hawke's Bay, New Zealand. Appl Water Sci 2:109-118

Beven KJ, Kirkby MJ (1979) A physically based, variable contributing area model of basin hydrology. Hydrol Sci Bull 24:43-69

Brunner GW (2008) HEC-RAS river analysis system user's manual version 4.0. In: US Army Corps of Engineers, Hydrologic Engineering Center. Davis

Ciarapica L, Todini E (2002) TOPKAPI: a model for the representation of the rainfall-runoff process at different scales. Hydrol Process 16:207-229

De Wit MJ (2001) Nutrient fluxes at the river basin scale. I: the PolFlow model. Hydrol Process 15:743-759

DHI (2000) MIKE SHE water movement-user manual. DHI Water and Environment, Hørsholm

Doll P, Kaspar F, Lehner B (2003) A global hydrological model for deriving water availability indicators: model tuning and validation. J Hydrol 270:105-134

Durdu ÖF (2005) GIS based PCRaster-POLFLOW approach to modeling of coupled surface water and groundwater hydrology in the Büyük Menderes catchment. In: Practices on River Basin Management

EPA (2000) Climate change vulnerability and adaption assessment of water resources in Ghana. EPA, Accra

Falkenmark M (1989) The massive water scarcity now threatening Africa-why isn't it being addressed? Ambio 18:112-118

Greffe F (2003) Material transport in the Norrström Drainage Basin: integrating GIS and hydrological process modelling. KTH, Stockholm

Havnø K, Madsen MN, Dørge J (eds) (1995) MIKE11—a generalized river modelling package. Water Resources Publications, Colorado

IPCC (2007) Contribution of Working Group II to the Fourth Assessment Report of the Intergovernmental Panel on Climate Change. Cambridge University Press, Cambridge, and New York

Jarsjö, J., Y. Shibuo, and G. Destouni. 2004. Using the PCRasterPOLFLOW approach to GIS-based modelling of coupled groundwater-surface water hydrology in the Forsmark Area. Stockholm University

Karssenberg D (1996) PCRaster Environmental Software. PCRaster Workbooks. Faculty of Geographical Sciences, Utrecht University. The Netherlands, Utrecht

Karssenberg D (2002) Building dynamic spatial environmental models Utrecht University. Utrecht

Langbein WB (1949) Annual Runoff in the United States. US Geological Survey Circular, Department of the Interior: Washington, DC

Ledger DC (1972) The Warwickshire Avon: a case study of water demands and water availability in an intensively used River System. Trans Inst Br Geogr 55:83-110

Meinardi C, Beusen A, Bollen M, Klepper O (1994) Vulnerability of diffuse pollution of European soils and groundwater. National Institute of Public Health and Environmental Protection (RIVM). Bilthoven

Moriasi DN, Arnold JG, Van Liew MW, Bingner RL, Harmel RD, Veith TL (2007) Model evaluation guidelines for systematic quantification of accuracy in watershed simulations. Trans ASABE 50:885-900

NASA (2004) The Shuttle Radar Topography Mission (SRTM)

Nash JE, Sutcliffe JV (1970) River flow forecasting through conceptual models part I-A discussion of principles. J Hydrol $10: 282-290$

Oki T, Kanae S (2006) Global hydrological cycles and world water resources. Science 313:1068-1072

Oki T, Agata Y, Kanae S, Saruhashi T, Yang D, Musiake K (2001) Global assessment of current water resources using total runoff integrating pathways. Hydrol Sci J 46:983-996

Opoku-Ankomah Y (2000) Climate change vulnerability and adaptation assessment of water resources in Ghana. EPA, Accra

Owusu G (2014) Re-engineering DEM to extract geomorphologic parameters for flood prediction in Ghana. J Geomatics 8

Kundzewicz ZW, Mata LJ, Arnell NW, Döll P, Kabat P, Jiménez B, Miller KA, Oki T, Sen Z, Shiklomanov IA (2007) Freshwater resources and their management. In: Climate Change 2008: Impacts, Adaptation and Vulnerability. Cambridge University Press, Cambridge

Takahashi K, Matsuoka Y, Shimada Y, Shimamura R (2000) Development of the model to assess water resource problems under climate change. A report of 8th Earth Environment Symposium

Turc L (1954) The water balance of soils Relation between precipitation evaporation and flow. Annales Agronomiques $5: 380-458$

Van Der Knijff JM, Youni J, De Roo APJ (2008) LISFLOOD: a GISbased distributed model for river basin scale water balance and flood simulation. Int J Geogr Inf Sci 24

Vorosmarty CJ, Green P, Salisbury J, Lammers RB (2000) Global water resources: vulnerability from climate change and population growth. Science 289:284-288

Wada Y (2008) Water stress over the year: quantitative analysis of seasonality and severity on a global scale. Utrecht University, Utrecht

Water-Resources-Commission (2012) Pra River Basin—integrated water resources management plan. Water Resources Commission, Accra

Wendland F (1992) Die Nitrabelastung in den Grundwasserlandschaften der "alten" Buneslander (BRD)". Bercht asu der Okologischen Forschung

Widen-Nilsson E, Halldin S, Xu C (2007) Global water-balance modelling with WASMOD-M: parameter estimation and regionalization. J Hydrol 340:105-118 